\author{
Maria TYCHANICZ-KWIECIEŃ ${ }^{1}$ \\ Aleksandra MAZUR ${ }^{2}$ \\ Paweł GIL ${ }^{3}$ \\ Rafał GALEK ${ }^{4}$
}

\title{
WPEYW OŻEBROWANIA RURY NA WARUNKI WYMIANY CIEPLA PRZY KONWEKCJI SWOBODNEJ W POWIETRZU
}

\begin{abstract}
Artykuł przedstawia wstępne wyniki pomiarów cieplnych rurowego wymiennika ciepła typu woda-powietrze, wykonanego z odcinków rur gładkich oraz ożebrowanych z żebrami śrubowymi. Stanowisko pomiarowe znajduje się na wyposażeniu Zakładu Termodynamiki Wydziału Budowy Maszyn i Lotnictwa Politechniki Rzeszowskiej. Dokonano pomiarów mocy cieplnej traconej przez przenikanie na rurze gładkiej oraz ożebrowanej w funkcji różnicy temperatury wody wlotowej i temperatury otoczenia oraz współczynników przenikania ciepła: rury gładkiej - odniesionego do powierzchni zewnętrznej oraz dla rury ożebrowanej - odniesionego do powierzchni całkowitej ożebrowania. Wyniki pomiarów wskazują, że moc cieplna rozpraszana do otoczenia wzrasta niemal trzykrotnie w wyniku zastosowania ożebrowania w stosunku do powierzchni gładkiej. Z kolei współczynnik przenikania ciepła określony dla rury gładkiej osiągnął wartość wielokrotnie większą niż dla rury ożebrowanej.
\end{abstract}

Słowa kluczowe: powierzchnie ożebrowane, przenikanie ciepła, konwekcja swobodna, moc cieplna

\section{Nomenklatura:}

$A$ - pole powierzchni,

$c$ - ciepło właściwe,

$d$ - średnica,

$g$ - grubość żebra,

$h$ - współczynnik przejmowania ciepła,

$L$ - długość rury,

$n$ - podziałka żeber,

\footnotetext{
${ }^{1}$ Corresponding author/autor do korespondencji: Maria Tychanicz-Kwiecień, Politechnika Rzeszowska, Powstańców Warszawy 8, 35-959 Rzeszów, tel. 17743 2299, e-mail: mtychanicz@prz. edu.pl

2 Aleksandra Mazur, Politechnika Rzeszowska, e-mail: aleksandra.mazur@interia.pl

${ }^{3}$ Paweł Gil, Politechnika Rzeszowska, e-mail: gilpawel@prz.edu.pl

${ }^{4}$ Rafał Gałek, Politechnika Rzeszowska, e-mail: rafalgalek@prz.edu.pl
} 
$R$ - opór cieplny,

$r$ - promień,

$\dot{Q}$ - moc cieplna,

$T$ - temperatura,

$\dot{V}$ - wydatek objętościowy wody,

$U$ - współczynnik przenikania ciepła,

\section{Symbole greckie:}

$\lambda$ - współczynnik przewodzenia ciepła,

$\eta$ - sprawność żebra,

$\rho$ - gęstość wody,

\section{Indeksy:}

1 - dotyczy rury zewnętrznej,

2 - dotyczy rury wewnętrznej,

3- dotyczy wymiaru bazowego ożebrowania,

4 - dotyczy wymiaru zewnętrznego ożebrowania,

b - dotyczy ożebrowania,

przejm. - dotyczy przejmowania ciepła,

przew. - dotyczy przewodzenia ciepła,

f_inn - dotyczy płynu wewnątrz rury (wody),

f_out - dotyczy płynu na zewnątrz rury (powietrze),

i - wewnętrzny (ang. inner),

$\mathrm{m} \dot{\mathrm{z}}$ - dotyczy przestrzeni międzyżebrowej,

o - zewnętrzny (ang. outer),

op - dotyczy rury gładkiej,

$\mathrm{r}$ - dotyczy rury,

wi - dotyczy ścianki wewnętrznej rury,

wo - dotyczy podstawy żebra,

wż- dotyczy wierzchołka żebra,

$\dot{z}-$ dotyczy żebra.

\section{Wprowadzenie}

Naturalny, konwekcyjny przepływ ciepła jest szeroko wykorzystywany w urządzeniach stosowanych w przemyśle i procesach technologicznych. Proces ten jednak cechuje się stosunkowo niskim współczynnikiem przenikania ciepła, z czego wynika konieczność prowadzenia badań nad intensyfikacją konwekcyjnej wymiany ciepła. Polega ona na zwiększeniu obciążenia cieplnego określonej powierzchni (wzrostu mocy cieplnej) przy określonym spadku temperatury. Cel ten można osiągnąć przez rozwinięcie powierzchni, tj. przez zastosowanie żeber [1] lub igieł bądź przez zwiększenie współczynnika przejmowania ciepła drogą sztucznej turbulizacji strumienia, lub przez sztuczne zrywanie laminarnej warstwy przyściennej [2]. Drugi z wymienionych sposobów sprowadza się właściwie 
do realizacji bardziej intensywnego mieszania płynu w warstwie przyściennej z płynem oddalonym od tej warstwy. Z reguły mieszanie to odbywa się sposobami mechanicznymi. Są jednak możliwe inne sposoby mieszania, jak np. przy wykorzystaniu strugi syntetycznej [3], ultradźwięków [4] lub wyładowań elektrycznych [5]. Wymienniki ciepła z powierzchniami ożebrowanymi znajdują szerokie zastosowanie w wielu gałęziach przemysłu, np. w chłodnictwie, wentylacji, motoryzacji i wielu innych.

Żebra mogą być wykorzystywane w celu zwiększenia powierzchni wymiany ciepła, zarówno powierzchni płaskich (np. płyta absorbera w panelu słonecznym [6]), jak i rur, na zewnętrz lub wewnątrz. Jeśli żebra występują zarówno wewnątrz, jak i na zewnątrz, to jest to wymiennik obustronnie żebrowany. Zastosowanie obustronnego ożebrowania rury może zwiększyć jej wydajność cieplną nawet o 260\% w stosunku do rur zewnętrznie ożebrowanych, ale wewnętrznie gładkich [7].

Wśród rozwiązań konstrukcyjnych stosowanych przy zwiększaniu powierzchni rur wyróżnia się m.in.: rury z żebrami wzdłużnymi, poprzecznymi, śrubowymi, okrągłymi i prostokątnymi. W zależności od technologii otrzymuje się żebra obwodowe rozmieszczone $\mathrm{z}$ daną podziałką lub żebra spiralne o określonym skoku. $Z$ uwagi na różnorodność procesów, technologii, jak i zastosowań powierzchni żebrowanych, w bibliografii można odnaleźć wiele badań dotyczących wyznaczenia charakterystyk cieplnych i przepływowych wymienników dla różnych parametrów konstrukcyjnych żeber czy też specyficznego zastosowania $[8,9]$. Na przykład w przypadku ożebrowania kanału w wymienniku krzyżowym rekuperatora bardziej korzystne pod względem efektywności wymiany ciepła jest wykorzystanie kanału o mniejszym przekroju i rzadszym ożebrowaniu niż o większym przekroju i gęstszym ożebrowaniu [10]. Natomiast w przypadku wymienników do odzysku ciepła z gazów spalinowych zastosowanie sinusoidalnych żeber w stosunku do spiralnie karbowanej rury pozwoliło zwiększyć wymianę ciepła o około 27,4-39,5\% [11].

W ostatnim czasie obserwuje się zainteresowanie miniaturyzacją urządzeń, w szczególności tych z zakresu wymiany ciepła [12], a więc i zastosowaniem mikrożeber w wymiennikach ciepła. W badaniach $[13,14]$ jednoznacznie wskazano, że miniaturyzacja w tym obszarze jest zasadna i korzystnie wpływa na proces wymiany ciepła, intensyfikując go.

Celem artykułu jest przedstawienie wpływu ożebrowania fragmentu powierzchni rurowego wymiennika ciepła na wymianę ciepła na drodze konwekcji swobodnej w powietrzu. Wymiennik ciepła typu woda-powietrze został wykonany z fragmentów rur gładkich oraz ożebrowanych. Określono moc cieplną przekazywaną do otoczenia dla rury gładkiej i ożebrowanej oraz współczynniki przenikania ciepła obydwu powierzchni. 


\section{Wymiana ciepła przez powierzchnie ożebrowane}

Stosowanie żeber jest celowe tylko w przypadku, gdy przez ożebrowanie powierzchni osiąga się zwiększenie strumienia wymienianego ciepła. Kryterium celowości stosowania żeber określa liczba Biota dla żebra $(\mathrm{Bi}<0,4)$ [15]. Żebro przewodzi ciepło od podstawy żebra (rury) do jego wierzchołka. Dodatkowo wzdłuż żebra zachodzi wymiana ciepła przez konwekcję. Dlatego na długości żebra powstaje spadek temperatury od $T_{\mathrm{wo}}$ do $T_{\mathrm{w} z}$ (rys. 1.). Stosowanie żeber jest celowe w przypadku, gdy powierzchnia jest omywana gazem. Zwiększenie strumienia ciepła przejmowanego od powierzchni użebrowanej można osiągnąć przez zmniejszenie odstępu pomiędzy żebrami. Daje to pożądany efekt, ale do pewnej granicznej wartości odstępu, przy której następuje zetknięcie warstw przyściennych powstałych na powierzchniach sąsiednich żeber.

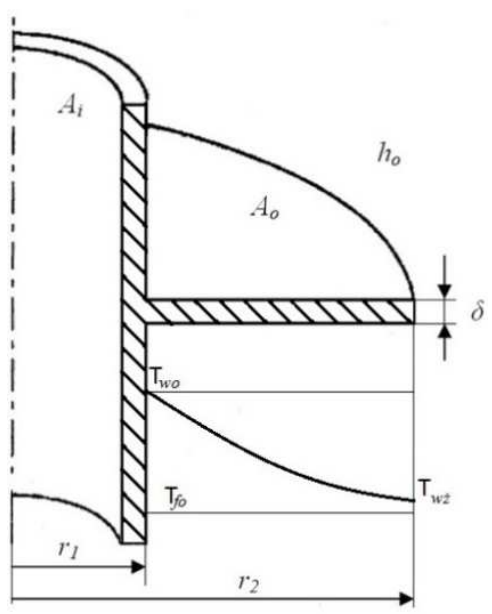

Rys. 1. Żebro okrągłe o stałej grubości

Fig. 1. Round fin of constant thickness

Skuteczność stosowania żeber ocenia się za pomocą sprawności żebra, która określa moc cieplną $\dot{Q}_{\dot{z}}$ przejmowaną od żebra przy rzeczywistym rozkładzie temperatury do mocy cieplnej $\dot{Q}_{\dot{z} \mathrm{~T}=\mathrm{T}_{\text {wo }}}$ przejmowanej od żebra przy stałej temperaturze żebra równej temperaturze nasady (podstawy) żebra $T_{\text {wo. }}$ Sprawność żebra jest określana wzorem:

$$
\eta_{\dot{\mathrm{z}}}=\frac{\dot{Q}_{\dot{\mathrm{z}}}}{\dot{Q}_{\dot{\mathrm{z}} T=T_{w o}}}
$$

Średnia temperatura żebra (o powierzchni zewnętrznej $A_{\dot{z}}$ ) jest obliczona jako:

$$
T_{\grave{\mathrm{z}}}=\frac{1}{A_{\dot{\mathrm{z}}}} \int_{A_{\dot{\mathrm{z}}}} T d A
$$


Jakościowy rozkład temperatury żebra $T_{\dot{z}}=f\left(r_{2}-r_{1}\right)$ zaprezentowano na rys. 1 . Określenie rozkładu temperatury wymaga skomplikowanego aparatu matematycznego, w związku z tym korzysta się z wykresów sprawności żebra, opracowanych przez innych badaczy. Przykład takiego wykresu pokazano na rys. 2.

W celu wyznaczenia sprawności żebra okrągłego, w pierwszej kolejności należy wyznaczyć wartość:

$$
m=\left(r_{2}-r_{1}\right) \sqrt{\frac{2 \cdot h_{\dot{z}}}{\lambda_{\dot{z}} \cdot g}}
$$

a następnie skorzystać z wykresu przedstawionego na rys. 2 .

Rys. 2. Sprawność żeber okrągłych o stałej grubości [15]

Fig. 2. The efficiency of round fins of constant thickness

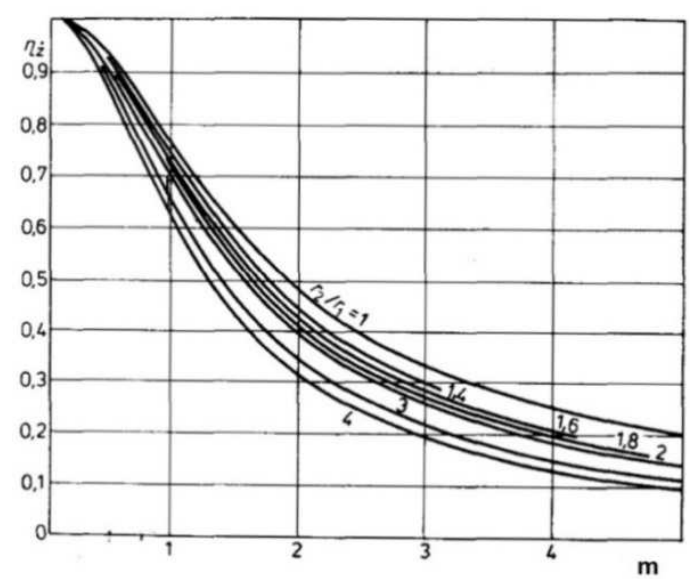

Intensywność procesu wymiany ciepła, zachodząca pomiędzy dwoma płynami oddzielonymi ścianką (przeponą, przegrodą), zależy od współczynników przejmowania ciepła płynów po obydwu stronach ścianki oraz od współczynnika przewodzenia ciepła i grubości ścianki. Moc cieplna $\dot{Q}$ przekazywana od płynu wewnętrznego o średniej temperaturze $T_{\mathrm{i}}$ do płynu zewnętrznego o średniej temperaturze $T_{\mathrm{o}}$ przez powierzchnię $A$ jest określona zależnością:

$$
\dot{Q}=U \cdot A \cdot\left(T_{\mathrm{i}}-T_{\mathrm{o}}\right)
$$

Współczynnik przenikania ciepła dla ścianki cylindrycznej (rurowej) odniesiony do powierzchni wewnętrznej jest opisany zależnością:

$$
\frac{1}{U}=\frac{1}{h_{\mathrm{i}}}+\frac{A_{\mathrm{i}} \cdot \ln \left(\frac{d_{o}}{d_{\mathrm{i}}}\right)}{2 \cdot \pi \cdot \lambda \cdot L}+\frac{A_{\mathrm{i}}}{A_{\mathrm{o}}} \frac{1}{h_{\mathrm{o}}}
$$


Równanie (5) można również zapisać jako:

$$
\frac{1}{U}=R_{\text {przejm_i }}+R_{\text {przew }}+R_{\text {przejm_o }}
$$

Przy zaniedbaniu oporu przewodzenia ścianki współczynnik przenikania ciepła będzie istotnie zależał od najmniejszej wartości współczynnika przejmowania ciepła ośrodka. Biorąc pod uwagę wartość współczynnika przejmowania ciepła w warunkach konwekcji swobodnej w powietrzu (około $4,33 \mathrm{~W} /\left(\mathrm{m}^{2} \mathrm{~K}\right.$ ) oraz w wodzie podczas konwekcji wymuszonej $\left(500-1000 \mathrm{~W} / \mathrm{m}^{2} \mathrm{~K}\right)$, intensyfikacja wymiany ciepła poprzez rozwinięcie powierzchni w postaci stosowania żeber w rurowym wymienniku ciepła typu woda-powietrze jest zasadna.

Współczynnik przenikania ciepła $U$ dla rur żebrowanych odniesiony do powierzchni wewnętrznej można wyznaczyć z zależności:

$$
\frac{1}{U}=\frac{1}{h_{\mathrm{i}}}+\frac{A_{\mathrm{i}} \cdot \ln \left(\frac{d_{\mathrm{ro}}}{d_{\mathrm{ri}}}\right)}{2 \cdot \pi \cdot \lambda \cdot L}+\frac{A_{\mathrm{i}}}{h_{\mathrm{m} \dot{\mathrm{z}}} \cdot A_{\mathrm{m} \dot{\mathrm{z}}}+h_{\grave{\mathrm{z}}} \cdot A_{\dot{\mathrm{z}}} \cdot \eta_{\grave{\mathrm{z}}}}
$$

Ponieważ pole powierzchni międzyżebrowej jest dużo mniejsze od pola powierzchni żeber $A_{\mathrm{mż}} \ll A_{\dot{z}}$, wówczas można założyć, że człon $h_{\mathrm{mż}} \cdot A_{\mathrm{mż}}$ w równaniu (7) jest równy zeru. Zatem równanie (7) przybiera postać:

$$
\frac{1}{U}=\frac{1}{h_{\mathrm{i}}}+\frac{A_{\mathrm{i}} \cdot \ln \left(\frac{d_{\mathrm{ro}}}{d_{\mathrm{ri}}}\right)}{2 \cdot \pi \cdot \lambda \cdot L}+\frac{A_{\mathrm{i}}}{h_{\mathrm{o}} \cdot A_{\mathrm{o}}}
$$

\section{Opis stanowiska badawczego}

Widok stanowiska badawczego przedstawiono na rys. 3. Głównymi elementami stanowiska są półmetrowe odcinki rury bimetalowej wysokożebrowanej oraz rury gładkiej. Rura jest wykonana z polerowanej stali nierdzewnej, natomiast żebra - z aluminium. Połączone równolegle rury są zasilane gorącą wodą z ultratermostatu (UT), przy czym dopływ czynnika do każdego odcinka można regulować za pomocą zaworu (Z1, Z2). Na wlocie i wylocie każdej z rur umieszczono termopary typu K (chromel-alumel) o spoinie pomiarowej długości ok. $1 \mathrm{~cm}$, sięgającej w przybliżeniu od osi rury do powierzchni jej ścianki wewnętrznej. Dodatkowa termopara umożliwia pomiar temperatury powietrza w laboratorium. $\mathrm{Na}$ wspólnym dla obu rur odcinku zasilania znajduje się licznik ciepła Kamstrup MULTICAL 402 dokonujący pomiaru temperatur na zasilaniu i powrocie oraz wydatku objętościowego czynnika.

Pomiar wartości rezystancji czujników Pt500 w liczniku ciepła jest wykonywany pośrednio. Przekroje poprzeczne rury ożebrowanej i gładkiej przedstawiono odpowiednio na rys. 4. oraz $5 . \mathrm{Z}$ kolei schemat stanowiska badawczego pokazano na rys. 6 . Wymiary geometryczne badanych rur wymiennika ciepła zestawiono w tab. 1. 


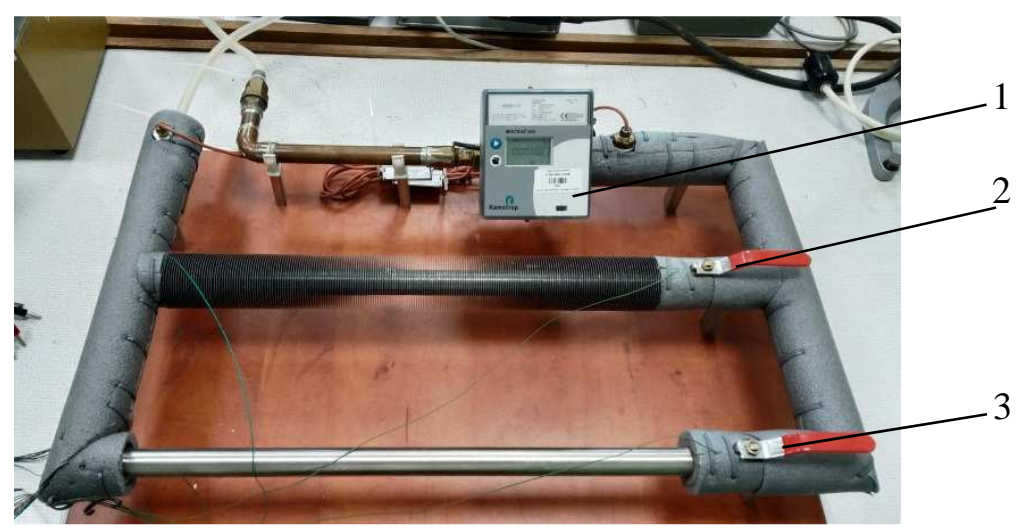

Rys. 3. Zdjęcie stanowiska badawczego: 1 - licznik ciepła Kamstrup MULTICAL 402, 2 - zawór rury ożebrowanej, 3 - zawór rury gładkiej

Fig. 3. A photo of experimental set-up: 1 - Kamstrup MULTICAL 402 heat meter, 2 - finned pipe valve, 3 - smooth pipe valve

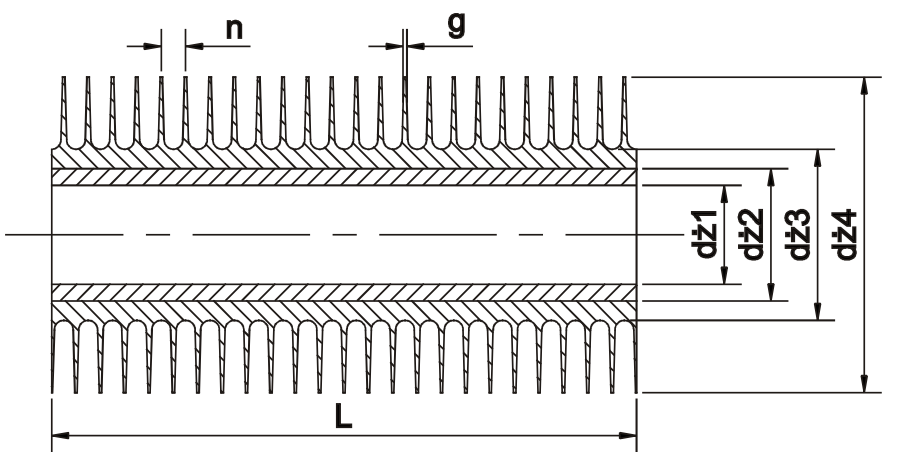

Rys. 4. Oznaczenia parametrów geometrycznych dla rury wysokożebrowanej

Fig. 4. Indications of geometrical parameters of a bimetal finned pipe

Rys. 5. Oznaczenia parametrów geometrycznych dla rury gładkiej

Fig. 5. Indications of geometrical parameters for a smooth pipe

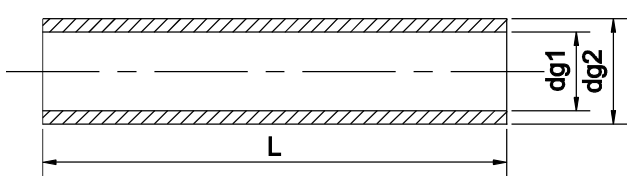




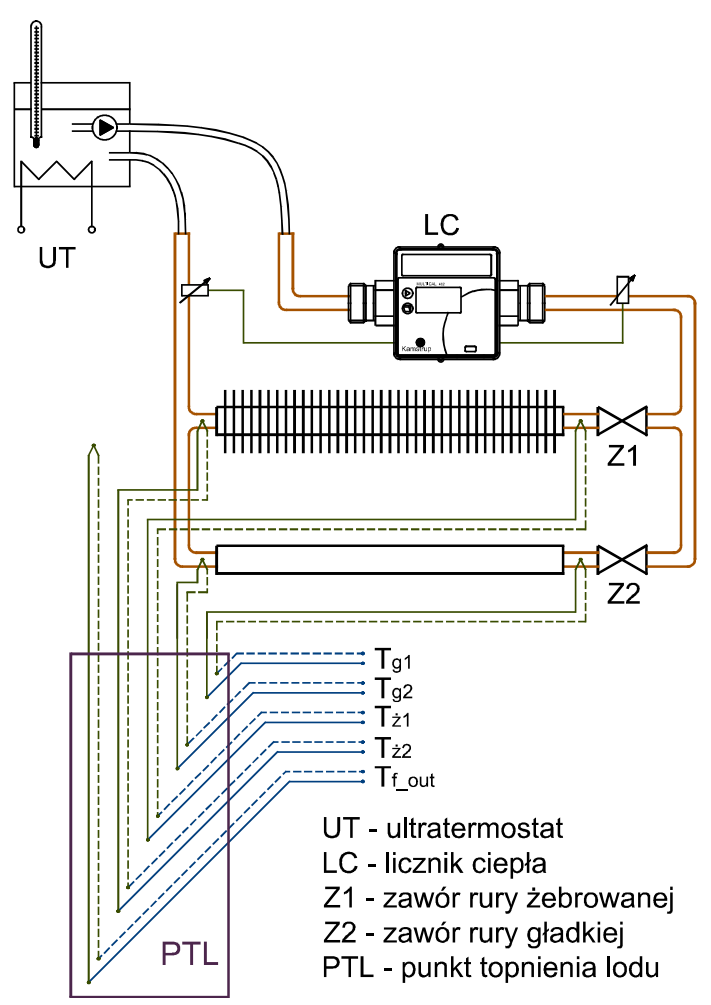

Rys. 6. Schemat stanowiska badawczego

Fig. 6. The schematic diagram of the experimental set-up

Tabela 1 . Wymiary badanych rur

Table 1. Dimensions of the investigated pipes

\begin{tabular}{|c|c|c|c|c|}
\hline & Parametr & Symbol & Wartość & Jednostka \\
\hline \multirow{7}{*}{ 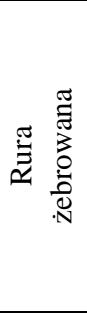 } & średnica wewnętrzna rury wewnętrznej & $d_{\dot{z} 1}$ & 22 & $\mathrm{~mm}$ \\
\hline & średnica zewnętrzna rury wewnętrznej & $d_{\dot{z} 2}$ & 25,4 & $\mathrm{~mm}$ \\
\hline & średnica bazowa ożebrowania & $d_{\dot{z} 3}$ & 26,6 & $\mathrm{~mm}$ \\
\hline & średnica zewnętrzna ożebrowania & $d_{\dot{z} 4}$ & 57 & $\mathrm{~mm}$ \\
\hline & podziałka żeber & $n$ & 2,5 & $\mathrm{~mm}$ \\
\hline & grubość żebra & $g$ & 0,35 & $\mathrm{~mm}$ \\
\hline & długość & $L$ & 0,5 & $\mathrm{~m}$ \\
\hline \multirow{3}{*}{ 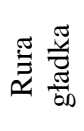 } & średnica wewnętrzna & $d_{\mathrm{g} 1}$ & 22 & $\mathrm{~mm}$ \\
\hline & średnica zewnętrzna & $d_{\mathrm{g} 2}$ & 25 & $\mathrm{~mm}$ \\
\hline & długość & $L$ & 0,5 & $\mathrm{~m}$ \\
\hline
\end{tabular}




\section{Metodyka badań}

Wymianę ciepła w stanie ustalonym dla bimetalowej rury żebrowanej opisują równania dotyczące następujących procesów:

1. Przejmowania ciepła wewnątrz rury:

$$
\dot{Q}_{\dot{\mathrm{z}}}=h_{\mathrm{i}} A_{\mathrm{i}}\left(T_{\mathrm{f}_{\text {_inn }}}-T_{\mathrm{wi}}\right)
$$

2. Przewodzenia ciepła:

$$
\dot{Q}_{\dot{\mathrm{z}}}=\frac{T_{\mathrm{wi}}-T_{\mathrm{wo}}}{\frac{\ln \left(\frac{d_{\dot{2} 2}}{d_{\dot{2} 1}}\right)}{2 \pi \lambda_{1} L}+\frac{\ln \left(\frac{d_{\dot{2} 3}}{d_{\dot{z} 2}}\right)}{2 \pi \lambda_{2} L}}
$$

3. Przejmowania ciepła na powierzchni zewnętrznej:

$$
\dot{Q}_{\dot{\mathrm{z}}}=h_{\mathrm{o}} A_{\mathrm{o}}\left(T_{\text {wo }}-T_{\text {f_out }}\right)
$$

4. Przenikania ciepła:

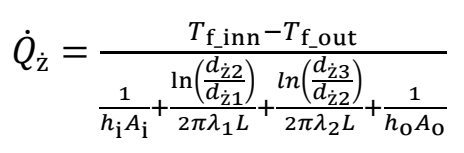

Występujący w przedstawionych wzorach współczynnik przejmowania ciepła, określony dla całego ożebrowania $h_{0}$, należy interpretować jako wielkość efektywną, zależną od warunków przejmowania ciepła wzdłuż żeber oraz na powierzchni międzyżebrowej:

$$
h_{o}=\eta_{\dot{\mathrm{z}}} h_{\dot{\mathrm{z}}} \frac{A_{\dot{\mathrm{z}}}}{A_{\mathrm{o}}}+h_{\mathrm{m} \dot{\mathrm{z}}} \frac{A_{\mathrm{m} \dot{\mathrm{z}}}}{A_{\mathrm{o}}}
$$

Powierzchnia całkowita ożebrowania jest sumą powierzchni żeber i powierzchni międzyżebrowej: $A_{o}=A_{\dot{z}}+A_{m \dot{z}} \cdot \mathrm{Z}$ wystarczającą dokładnością można ją obliczyć ze wzoru:

$$
A_{o}=\pi d_{3} L+2 i\left(\frac{\pi d_{4}^{2}}{4}-\frac{\pi d_{3}^{2}}{4}\right)=\pi d_{3} L+\frac{\pi i}{2}\left(d_{4}^{2}-d_{3}^{2}\right)
$$

gdzie: $\mathrm{i}=\frac{\mathrm{L}}{\mathrm{n}}-$ liczba żeber.

Powierzchnię bazową ożebrowania $A_{\mathrm{b}}$ można obliczyć w oparciu o średnicę podstawy żeber z zależności:

$$
A_{b}=\pi d_{3} L
$$


Wymiana ciepła dla rury gładkiej jest opisana wzorami analogicznymi do równań (9)-(12), przy czym mianownik we wzorach (10)-(12) nie uwzględnia wyrazów związanych z przewodzeniem ciepła, a współczynniki przejmowania ciepła $h_{\mathrm{i}}$ oraz $h_{\mathrm{o}}$ odnoszą się odpowiednio do powierzchni wewnętrznej i zewnętrznej rury gładkiej. W trakcie badań zmierzono wartości temperatur na wlocie i wylocie odpowiednio dla rury gładkiej i żebrowanej $\left(T_{\mathrm{g} 1}, T_{\mathrm{g} 2}, T_{\bar{z} 1}, T_{\mathrm{z} 2}\right)$ oraz temperaturę powietrza na zewnątrz rur w obszarze niezaburzonym przez wpływ konwekcji swobodnej $T_{\mathrm{f}_{\mathrm{o}} \text { out. }}$ Temperaturę wody wewnątrz rur można obliczyć jako średnią arytmetyczną temperatury wlotowej i wylotowej:

$$
\begin{aligned}
& T_{\mathrm{f}_{-} \mathrm{inn} \_\mathrm{g}}=\frac{T_{\mathrm{g} 1}+T_{\mathrm{g} 2}}{2} \\
& T_{\mathrm{f}_{-} \mathrm{inn}_{\_} \dot{\mathrm{z}}}=\frac{T_{\dot{\mathrm{z}} 1}+T_{\mathrm{z} 2}}{2}
\end{aligned}
$$

Pomiar spadku temperatury na odcinku rury pozwala na określenie mocy cieplnej wymienianej z otoczeniem:

$$
\begin{aligned}
& \dot{Q}_{\mathrm{g}}=\rho c_{\mathrm{w}} \dot{V}\left(T_{\mathrm{g} 1}-T_{\mathrm{g} 2}\right) \\
& \dot{Q}_{\dot{\mathrm{z}}}=\rho c_{\mathrm{w}} \dot{V}\left(T_{\dot{\mathrm{z}} 1}-T_{\dot{\mathrm{z}} 2}\right)
\end{aligned}
$$

Gęstość wody $\rho$ należy określać dla temperatur wlotowych $T_{\mathrm{g} 1}$ i $T_{\dot{z} 1}$, natomiast ciepło właściwe $c_{\mathrm{w}}$ dla temperatur $T_{\mathrm{f}_{\_} i n n \_\mathrm{g}} \mathrm{i} T_{\mathrm{f}_{\_} \text {inn_ż. }}$. Wyznaczoną w ten sposób moc cieplną można wyrazić również, za pomocą temperatur płynu wewnątrz i na zewnątrz rury, zależnością o ogólnej postaci:

$$
\dot{Q}=U A\left(T_{\mathrm{f}_{-} \text {inn }}-T_{\mathrm{f}_{-} \text {out }}\right)
$$

gdzie $U$ oznacza współczynnik przenikania ciepła odniesiony do powierzchni $A$. Na tej podstawie można określić wartość współczynnika przenikania ciepła rury gładkiej odniesioną do jej powierzchni zewnętrznej:

$$
U_{\text {go }}=\frac{\dot{Q}_{\mathrm{g}}}{A_{\text {go }}\left(\mathrm{T}_{\mathrm{f}_{-} \text {inn_g }}-T_{\mathrm{f}_{\mathrm{o}} \text { out }}\right)}
$$

gdzie: $A_{g o}=\pi d_{\mathrm{g} 2} L$.

Wartość współczynnika przenikania ciepła rury żebrowanej odniesiona do powierzchni bazowej ożebrowania:

$$
U_{\dot{\mathrm{z}} \mathrm{b}}=\frac{\dot{Q}_{\dot{\mathrm{z}}}}{A_{\mathrm{b}}\left(T_{\mathrm{f}_{\_} \text {inn } \dot{\mathrm{z}}_{-}}-T_{\mathrm{f}_{-} \text {out }}\right)}
$$


Z kolei wartość współczynnika przenikania ciepła rury żebrowanej odniesiona do powierzchni całkowitej ożebrowania:

$$
U_{\dot{z} O}=\frac{\dot{Q}_{\dot{z}}}{A_{\text {o }}\left(T_{\mathrm{f}_{-} \text {inn } \dot{z}_{\text {z }}}-T_{\mathrm{f}_{-} \text {out }}\right)}
$$

\section{Wyniki pomiarów}

Pomiary wykonano dla trzech wartości różnicy temperatur pomiędzy wodą wlotową a temperaturą otoczenia: $32^{\circ} \mathrm{C}, 45^{\circ} \mathrm{C}$ i $72^{\circ} \mathrm{C}$. Na rysunku 7. przedstawiono zależność mocy cieplnej oddanej do otoczenia w wyniku konwekcji swobodnej dla rury gładkiej i ożebrowanej w funkcji różnicy temperatury wody wlotowej do wymiennika i temperatury otoczenia.

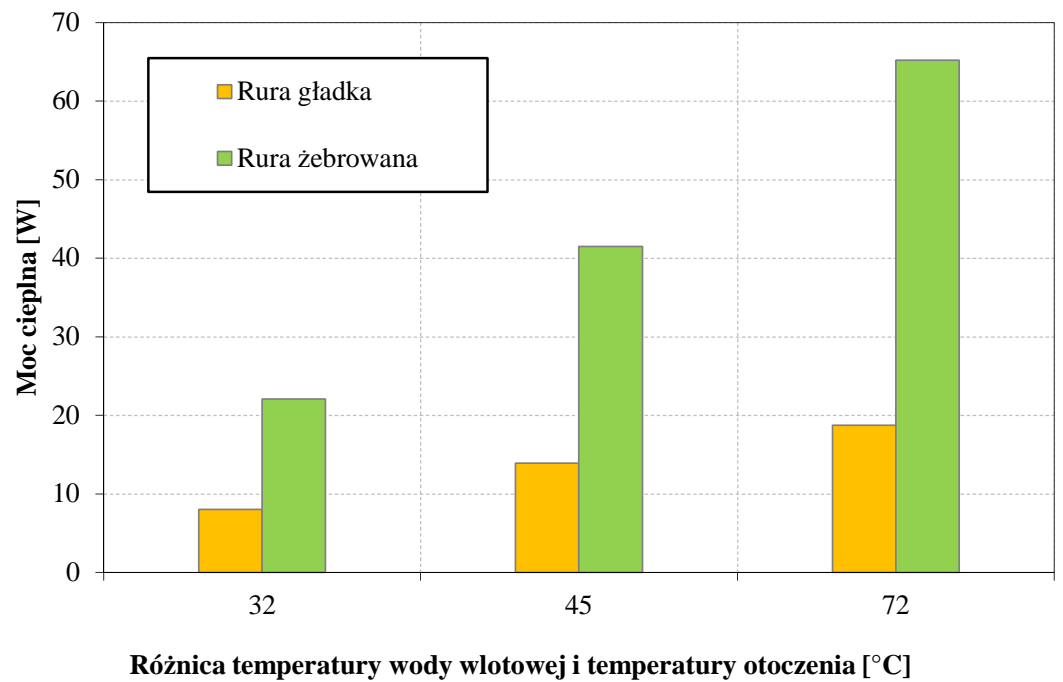

Rys. 7. Zależność mocy cieplnej od różnicy temperatur wody wlotowej i temperatury otoczenia dla rury gładkiej i ożebrowanej

Fig. 7. Thermal power as a function of temperature difference between inlet water temperature and ambient temperature for a finned and a smooth pipe

Jak wynika z rysunku 7., ilość ciepła przekazana do otoczenia wzrasta wraz ze wzrostem różnicy temperatur pomiędzy wodą wlotową i temperaturą otoczenia i jest zdecydowanie większa dla wymiennika ożebrowanego przy tej samej długości urządzenia, co wynika ze zwiększonej powierzchni wymiany ciepła. Analogicznie przyrost mocy cieplnej wraz ze wzrostem różnicy temperatur jest większy dla rury ożebrowanej. 
Na rysunku 8. zestawiono wyznaczone współczynniki przenikania ciepła dla rury gładkiej i ożebrowanej. W przypadku rury ożebrowanej współczynnik przenikania ciepła nie jest wprost proporcjonalny do wzrastającej różnicy temperatur, jego największą wartość zaobserwowano dla różnicy temperatur $45^{\circ} \mathrm{C}$, co może wynikać z niepewności pomiaru. Dla rury gładkiej o tej samej długości wyznaczony współczynnik przenikania ciepła jest ponad siedmiokrotnie większy i wynosi maksymalnie około $8 \mathrm{~W} /\left(\mathrm{m}^{2} \cdot \mathrm{K}\right)$. Analizując proces wymiany ciepła w przedstawionym układzie, należy rozpatrzyć wpływ radiacyjnej wymiany ciepła. Ze względu na niską emisyjność materiału rury (polerowana stal nierdzewna, $\varepsilon=0,1$ ) oraz żebra (aluminium, $\varepsilon=0,2$ ) radiacyjny współczynnik przejmowania ciepła przyjmuje pomijalnie małą wartość, w związku z czym straty ciepła przez promieniowanie również mogą być pominięte.

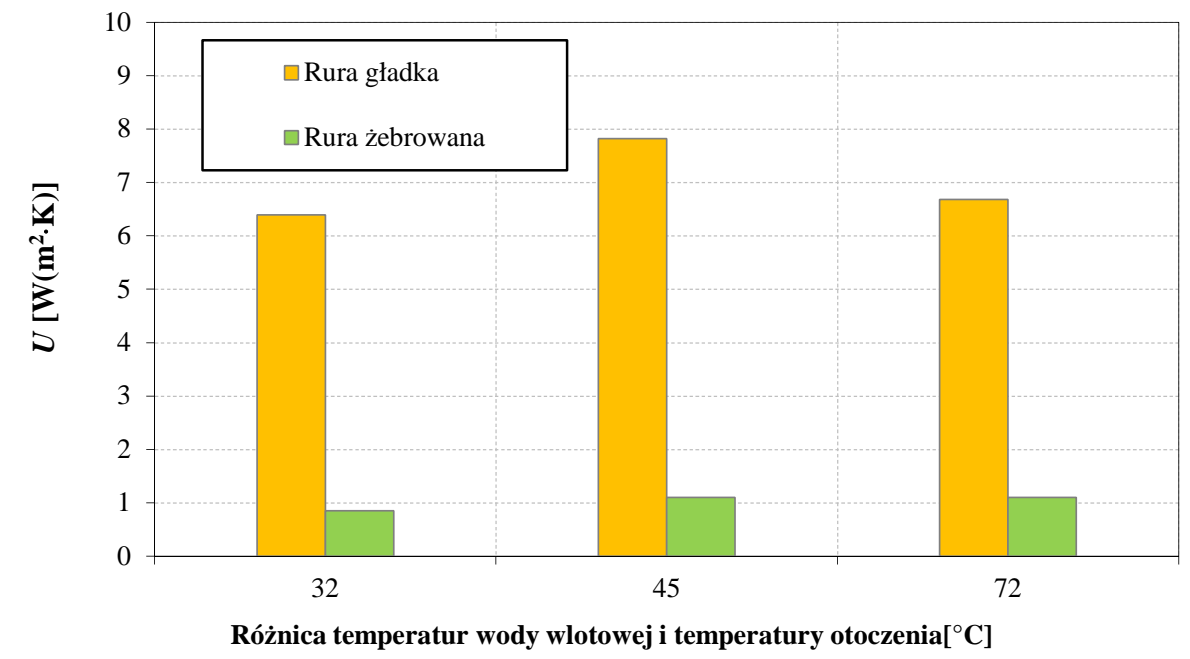

Rys. 8. Zależność współczynnika przenikania ciepła od różnicy temperatur wody wlotowej i temperatury otoczenia dla rury gładkiej i ożebrowanej

Fig. 8. Heat transfer coefficient as a function of temperature difference between inlet water temperature and ambient temperature for a finned and a smooth pipe respectively

Wyznaczono również stosunek mocy cieplnej rury ożebrowanej i rury gładkiej w zależności od różnicy temperatury wody wlotowej i temperatury otoczenia, a wyniki przedstawiono na rys. 9. Im wyższa jest różnica temperatur, tym większa jest różnica mocy cieplnej rury gładkiej i ożebrowanej. Stosunek mocy cieplnej wzrasta o około $26 \%$ w miarę wzrostu różnicy temperatur na skutek intensyfikacji konwekcyjnej wymiany ciepła. 


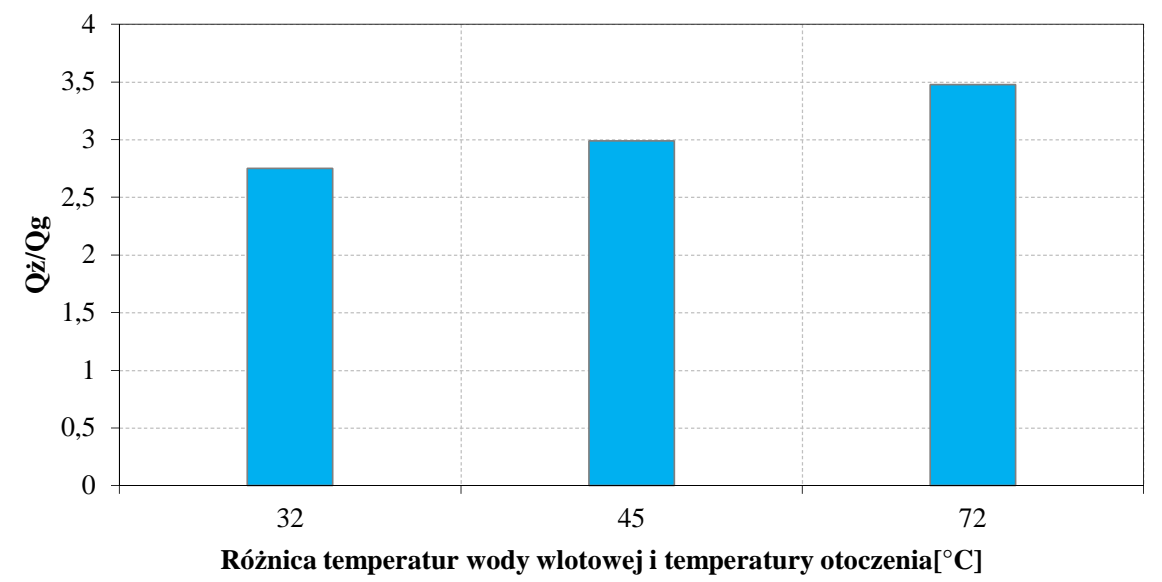

Rys. 9. Stosunek mocy cieplnej rury ożebrowanej i gładkiej w funkcji różnicy temperatur wody wlotowej i temperatury otoczenia

Fig. 9. The ratio of thermal power for finned and smooth pipe as a function of temperature difference between inlet water temperature and ambient temperature

\section{Podsumowanie}

W wielu procesach technicznych i przemysłowych jest pożądana jak największa intensyfikacja wymiany ciepła. Intensyfikacja tego zjawiska jest możliwa m.in. przez rozwinięcie powierzchni wymiany ciepła, np. przez ożebrowanie powierzchni. Celem artykułu było określenie wpływu ożebrowania powierzchni rury na intensyfikację konwekcyjnej wymiany ciepła w powietrzu.

Analizie poddano rurowy wymiennik ciepła, składający się z jednakowej długości odcinków rury gładkiej i ożebrowanej z zewnętrznymi żebrami śrubowymi. Wykonano wstępne pomiary cieplne wymiennika, w tym określono moc cieplną przekazywaną do otoczenia oraz współczynniki przenikania ciepła odpowiednio dla powierzchni gładkiej oraz ożebrowanej.

$\mathrm{Z}$ przeprowadzonych badań wynika, że zastosowanie ożebrowania powierzchni nie przyczyniło się do intensyfikacji konwekcyjnej wymiany ciepła, o czym świadczy wielokrotnie większa wartość współczynnika przenikania ciepła dla rury gładkiej (około $7 \mathrm{~W} / \mathrm{m}^{2} \mathrm{~K}$ ) niż dla rury ożebrowanej (około $1 \mathrm{~W} / \mathrm{m}^{2} \mathrm{~K}$ ). Moc cieplna rozpraszana do otoczenia dla rury ożebrowanej wzrasta tylko 3-krotnie, pomimo zwiększenia pola powierzchni wymiany ciepła 21-krotnie. Biorąc pod uwagę wartość współczynnika przejmowania ciepła po stronie wody (około $120 \mathrm{~W} / \mathrm{m}^{2} \mathrm{~K}$ ), należy stwierdzić, że opór przejmowania ciepła po stronie wody jest niewielki.

Dodatkowo do wyznaczenia współczynnika przejmowania ciepła wykorzystano korelację Michiejewa na liczbę Nusselta dla przepływu laminarnego w kanale. Uwzględniając również wysoką, określoną sprawność żebra (ponad 90\%), można przypuszczać, że nieproporcjonalny względem powierzchni wymiany 
ciepła wzrost mocy cieplnej może wynikać z faktu nałożenia się warstw przyściennych w przestrzeni międzyżebrowej w wyniku zbyt małej podziałki żeber.

\section{Literatura}

[1] Acharya S., Dash S.K.: Natural convection heat transfer from a horizontal hollow cylinder with internal longitudinal fins, Int. J. Thermal Sci., 134 (2018) 40-53.

[2] Goodrich S.S., Marcum W.R.: Natural convection heat transfer and boundary layer transition for vertical heated cylinders, Exp. Thermal Fluid Sci., 105 (2019) 367-380.

[3] Gil P.: Synthetic jet Reynolds number based on reaction force measurement, J. Fluids Structures, 81 (2018) 466-478.

[4] Bulliard-Sauret O., Berindei J., Ferrouillat S., Vignal L., Memponteil A., Poncet C., Leveque J.M., Gondrexon N.: Heat transfer intensification by low or high frequency ultrasound: Thermal and hydrodynamic phenomenological analysis, Exp. Thermal Fluid Sci., 104 (2019) 258-271.

[5] Lai F.C.: Electrohydrodynamic-enhanced natural convection in an enclosure by a nonsymmetric electric field, J. Thermophysics Heat Transfer, 33 (2019) 441-448.

[6] Kumar A., Layek A.: Nusselt number and friction factor correlation of solar air heater having twisted-rib roughness on absorber plate, Renewable Energy, vol. 130 (2019) 687-699.

[7] Pasierb A., Schweitzer K.H.: Nowe rozwiązania rur obustronnie żebrowanych z wirowym przepływem medium wewnątrz rury, Rudy Metale, 49 (2004) 521-524.

[8] Jedsadaratanachai W., Boonloi A.: Performance analysis and flow visualization in a round tube heat exchanger inserted with wavy V-ribs, Adv. Mech. Eng., 9 (2017) $1-16$.

[9] Zheng N.B., Liu P., Liu Z.C., Liu W., Numerical simulation and sensitivity analysis of heat transfer enhancement in a flat heat exchanger tube with discrete inclined ribs, Int. J. Heat Mass Transfer, 112 (2017) 509-520.

[10] Pandelidis D., Anisimov S.: Analiza konstrukcji wymienników wyparnych na przykładzie wymiennika krzyżowego: wyniki symulacji numerycznej, Rynek instalacyjny, 10 (2014) 64-70.

[11] Hong Y., Du J., Li Q., Xu T., Li W.: Thermal-hydraulic performances in multiple twisted tapes inserted sinusoidal rib tube heat exchangers for exhaust gas heat recovery applications, Energy Conversion Management, 185 (2019) 271-290.

[12] Pal S.K., Bhattacharyya S., Pop I.: A numerical study on non-homogeneous model for the conjugate-mixed convection of a $\mathrm{Cu}$-water nanofluid in an enclosure with thick wavy wall, Appl. Math. Computation, 356 (2019) 219-234.

[13] Eiamsa-ard S., Wongcharee K.: Convective heat transfer enhancement using $\mathrm{Ag}$-water nanofluid in a micro-fin tube combined with non-uniform twisted tape, Int. J. Mech. Sci., 146 (2018) 337-354.

[14] Rao Y., Chen P., Wan CY.: Experimental and numerical investigation of impingement heat transfer on the surface with micro W-shaped ribs, Int. J. Heat Mass Transfer, 93 (2016) 683-64.

[15] Wiśniewski S., Wiśniewski T.S.: Wymiana ciepła, WNT, Warszawa 2000. 
THE INFLUENCE OF FINS ON HEAT TRANSFER PERFORMANCE UNDER FREE CONVECTION IN AIR

\section{S u m m a r y}

The article presents preliminary results of thermal parameter measurements of an air-water tubular heat exchanger made of smooth- and finned pipes. The experimental set-up is the equipment of The Department of Thermodynamics at Rzeszow University of Technology. The following parameters have been measured as a function of temperature difference between inlet water temperature and ambient temperature: dissipated thermal power for smooth- and finned pipes and the heat transfer coefficient for a smooth pipe related to the external surface and heat transfer coefficient for a finned pipe related to the overall finned surface. The results indicate that dissipated thermal power increased almost three times for the finned pipe with regard to the smooth pipe. The heat transfer coefficient obtained for a smooth pipe was considerably greater than for a finned pipe.

Keywords: fins, heat transfer, free convection, thermal power

DOI: $10.7862 / \mathrm{rm} .2019 .08$

Otrzymano/received:12.06.2019 r.

Zaakceptowano/accepted: 14.07.2019 r. 
